\title{
1. Introduction: Asian subregions, environmental regimes and regime effectiveness
}

\section{OVERVIEW}

This chapter introduces the book, setting out the scope and aims, and outlines the research questions and methodology. Nine environmental regimes, together with other arrangements in Asian subregions, are evaluated and compared in the other chapters, most of which are situated within an international law framework. While this is the primary discipline on which the analysis is based, the book also draws on notions of effectiveness as developed by the international relations scholarship. ${ }^{1} \mathrm{~A}$ common framework for analysing each of the regimes in Chapters 2-4 (and also one regime in Chapter 5), is explained and justified, with reference also to the scholarship of international political economy and global politics/geopolitics more broadly. This will assist with the future elaboration of a proposed international law framework for the protection of the environment of the 'Third Pole' in Chapter 5;2 this draws on both hard and soft law, in recognition of existing treaty-based and other

1 See for example, Alice Park Lee and Shunji Matsuoka, 'Effectiveness of International Institutions: How to Build an Analytical Framework?', paper presented to the Conference on the Human Dimensions of Global Environmental Change, Amsterdam, 2-4 December 2009; H Breitmeier, OR Young and M Zurn, Analysing International Environmental Regimes: From Case Study to Database (MIT Press, Cambridge, 2006); Edward L Miles, Steiner Andresen, Elaine M Carlin, Jon Birger Skjaerseth, Arild Underdal and Jorgen Wetterstad, Environmental Regime Effectiveness: Confronting Theory with Evidence (MIT Press, Cambridge, 2002); Oran R Young (ed), The Effectiveness of International Environmental Regimes (MIT Press, Cambridge, 1999). See also N Kanie, $\mathrm{S}$ Andresen and PM Haas (eds), Improving Global Environmental Governance: Best Practices for Architecture and Agency (Routledge, Abingdon, 2014).

2 Falk Huettmann, 'Introduction: Why Three Poles and Why Protect Them', in Falk Huettmann (ed), Protection of the Three Poles (Springer, Japan, 2012) 3-32. 
mechanisms. The Third Pole is constituted mainly by the Himalayas/ Tibetan Plateau; in light of territorial, security and resource issues, such a proposal will inevitably be contested and controversial. Nonetheless, recommendations and suggestions for this are made in an effort to add a legal discourse to acknowledged environmental and other concerns.

Chapter 1 also outlines and distinguishes between regions and subregions ${ }^{3}$ with reference to Asia, ${ }^{4}$ and discusses regimes generally and environmental regimes specifically from the international law, international relations and international development literatures. ${ }^{5}$ There is a need to both define and contextualize regions and subregions generally, ${ }^{6}$ and specifically regimes and subregimes in Asia. The chapter therefore considers the geography of Asia as a region and the environmental issues it faces, before examining the numerous international and regional institutions that operate there. It also considers the discourse and scholarship in connection with regions and subregions developed by these institutions and academic commentaries, with a focus on the development of institutions to respond to the needs identified. It examines the (primarily

3 For early reviews, see Luk Van Langenhove, 'Theorising Regionhood' UNU-CRIS Working Papers, W-2003/1 (United Nations University, Brugge, 2003); Rodrigo Tavares, 'The State of the Art of Regionalism: The Past, Present and Future of a Discipline' UNU-CRIS Working Papers W-2004/10 (United Nations University, 2004) 1-29; and Nikki Slocum and Luk Van Langenhove, 'The Meaning of Regional Integration: Introducing Positioning Theory in Regional Integration Studies' UNU-CRIS e-Working Papers W-2003/5 (United Nations University, 2003) 1-49.

4 Note the work of the Asian Development Bank (ADB) in taking forward this agenda: Asian Development Bank, Emerging Asian Regionalism: A Partnership for Shared Prosperity (ADB, Manila, 2008); and with respect to central Asia, Asian Development Bank, Environment Division, Central Asia Environments in Transition (Manila, 1998).

5 In an Asian context, see for example, 'Regime Theory' in H Litta, Regimes in Southeast Asia: An Analysis of Environmental Cooperation (Verlag Springer, Wiesbaden, 2012) 45-74.

6 For recent reviews, see: Louise Fawcett, 'The History and Concept of Regionalism' UNU-CRIS Working Papers W-2013/5 (United Nations University, 2013) 1-19; Emil Kirchner and Roberto Dominguez, 'Security Governance in a Comparative Regional Perspective' UNU-CRIS Working Papers W-2013/8 (United Nations University, Brugge, 2013) 1-28; and Lorenzo Fioramonti, 'The Evolution of Supranational Regionalism: From Top-down Regulatory Governance to Sustainability Regions?' UNU-CRIS Working Papers W-2014/2 (United Nations University, Brugge, 2014) 1-26. The latter paper concludes (p18) that climate change and energy needs are as important as the global financial crisis to explain the resurgence of regionalism in recent times. 
international relations) scholarship in connection with regimes and subregimes, before the notion and practicality of regime effectiveness (again primarily as advanced by international relations scholars), is considered.

The effectiveness of regimes under regime theory is discussed in some detail to establish the evaluation framework to be applied to the regimes in the substantive Chapters 2-4 that follow (and also to the one regime in Chapter 5). An outline of each of the chapters that constitute the book ends this first chapter. The analysis framework is developed with reference to international best practice, following an examination of the approach taken to multilateral environmental agreements (MEAs), in particular from the international law literature. The application of the United Nations Environment Programme (UNEP) support for MEAs is a key part of this framework; together with the UN Regional Commissions, ${ }^{7}$ UNEP's role in regionalism has been significant, as seen in the Regional Seas Programme for example, on which three of the regimes in particular are based (the Arabian Gulf/Gulf of Oman, Red Sea/Gulf of Aden, and the Caspian Sea). ${ }^{8}$ Another key part of the analysis framework draws on the findings of a related book project concluded in $2015 ;{ }^{9}$ with a concentration on implementation and compliance, findings from this with respect to National Implementation Reports (NIRs) and international Non-Compliance Procedures (NCPs) will also be focused upon in the framework. Finally, in recognition of the importance of international political economy ${ }^{10}$ as well as regime theory, the policies and practices of multilateral development banks (MDBs)/international financial institutions (IFIs) are also included in the analysis framework. These are below.

7 <http://www.regionalcommissions.org/> accessed 10/3/15. See also text

$8<$ http://www.unep.org/regionalseas/programmes/default.asp $>$ accessed 29/2/16. See generally Elizabeth Maruma Mrema, 'Regional Seas Programme: The Role Played by UNEP in its Development and Governance' in David Attard, Malgosia Fitzmaurice, Norman Martinez and Riyaz Hamza (eds), The IMLI Manual on International Maritime Law, Vol III, Marine Environmental Law and International Maritime Security Law (Oxford, Oxford University Press, 2016); and in connection with regime effectiveness, see also: David Johnson, Angela Benn and Maria Adelaide Ferreira, Measuring Success: Indicators for the Regional Seas Conventions and Action Plans (United Nations Environment Programme, 2014).

9 Simon Marsden and Elizabeth Brandon, Transboundary Environmental Governance in Asia: Practice and Prospects with the UNECE Agreements (Edward Elgar Publishing, Cheltenham, 2015).

10 Peter Newell, 'The Political Economy of Global Environmental Governance' (2008) 34(3) Review of International Studies 507-529. 
significant because environmental protection requirements from international law are expected to be implemented in domestic legal systems prior to lending by MDBs/IFIs regardless of whether a state is a member of the relevant agreement or not. ${ }^{11}$ Lending institutions have also been involved in the regime building itself, which has relevance for the Third Pole, in particular as seen in Chapter 5. Finally, in addition to its role in connection with each of the other subregions, the position of China is examined further in the last chapter.

\section{SCOPE AND AIM OF THE BOOK}

The book is an interdisciplinary analysis of inland, coastal and marine environmental regimes in Asia at the subregional level, ${ }^{12}$ which are overwhelmingly transboundary in nature. ${ }^{13}$ Particular disciplines are international environmental law, international relations and environmental management. These include regimes for the two UNEP 'Regional Seas' of southwest Asia (the 'Middle East'); the inland seas of central Asia (one part of this programme also); and rivers and their basins in southeast and northeast Asia. While still relevant, much of the previous scholarship in this area is now considerably dated, ${ }^{14}$ and current work focuses on a limited range of regimes and comparisons. ${ }^{15}$ Both past and current work

11 Marsden and Brandon, above n. 9,

12 For further examples, see Robin Warner and Simon Marsden (eds) Transboundary Environmental Governance: Inland, Coastal and Marine Perspectives (Ashgate, Farnham, 2012).

13 Louis L Kotzé, Global Environmental Governance: Law and Regulation for the 21st Century (Edward Elgar Publishing, Cheltenham, 2012); and Louis L Kotzé and Thilo Marauhn (eds), Transboundary Governance of Biodiversity (Brill Nijhoff, 2014).

14 Kazu Kato and Wakana Takahashi, Regional/Subregional Environmental Cooperation in Asia (Institute for Global Environmental Strategies, 2001); and Nathan Badenoch, Transboundary Environmental Governance: Principles and Practice in Mainland Southeast Asia (World Resources Institute, 2002). Notable exceptions include: Jörg Balsiger and Aysun Uyar (eds), Comparing Regional Environmental Governance in East Asia and Europe: Proceedings (Research Institute for Humanity and Nature, Kyoto, 2013); and H Litta, Regimes in Southeast Asia: An Analysis of Environmental Cooperation (Verlag Springer, Wiesbaden, 2012).

15 H Litta, 'Comparison and Reflection: A Conclusion' in H Litta, Regimes in Southeast Asia: An Analysis of Environmental Cooperation (Verlag Springer, Wiesbaden, 2012) 189-200; in this case, water issues in the Mekong and transboundary haze pollution. 
primarily concerns international law, relations and politics, and focuses on environment and development issues. The book updates this work by analysing regimes and other arrangements across southwest, central, southeast, east and south Asia; most have a legal underpinning of an international agreement, the majority of which are in force. It takes this further by adding recent information and analysis in connection with the most important recent player in many of these regimes, China. Based on the findings of each of the chapters, in Chapter 5 (south and east Asia), the book identifies the absence of a comprehensive regime for the Himalayas/Tibetan Plateau, notably for the protection of the mountains and related waters of what is known as the Third Pole. ${ }^{16}$ Based on the experience of the other subregions, it makes suggestions for the development of such a regime.

The role of China in the existing regimes is examined at the end of Chapters 2, 3 and 4, and, with regard to east Asia specifically, in Chapter 5, whether as Party or Dialogue Partner to an agreement, or as financier, and/ or developer in relation to the subregion in which the regime operates. China has a role to play as the state with the responsibility for the Tibetan Plateau - and interests across many of the regimes - it is therefore of key significance in the elaboration of a potential regime for the Third Pole, which is therefore examined based upon existing experience. ${ }^{17}$ Together with India - which also shares many borders with other states in this subregion and has a similar focus on rapid development - cooperative efforts are urgently needed to address the implications of failing to develop

16 Agreements for transboundary rivers are the exception in south Asia; India for example has adopted a number of treaties with its neighbours including the Indus Waters Treaty between the Government of India and the Government of Pakistan (Karachi, 19 September 1960), 419 UNTS 126, in force 1 January 1961. See Philippe Cullet and Joyeeta Gupta, 'India: Evolution of Water Law and Policy' in Joseph W Dellapenna and Joyeeta Gupta (eds), The Evolution of the Law and Politics of Water (Springer, 2009) 166-167.

17 Simon Marsden, 'Developing Approaches to Transboundary Environmental Impact Assessment in China: Cooperation through the Greater Tumen Initiative and in the Pearl River Delta Region' (2010) 9(2) Chinese Journal of International Law 393-414; Simon Marsden, 'Assessment of Transboundary Environmental Effects in the Pearl River Delta Region: Is There a Role for Strategic Environmental Assessment?' (2011) 31(6) Environmental Impact Assessment Review 593-601; and Simon Marsden, 'Cooperative Environmental Planning in China's Pearl River Delta Region', in C Andressen, AR Mubarak and X Wang (eds), Sustainable Development in China (Routledge, Abingdon, 2013) 152-163. 
such a regime. ${ }^{18}$ These include the likely significant negative transboundary environmental effects of massive dam-building programmes of both nations and others, and the potential harm caused by exploration and exploitation of energy resources, as and when they are discovered and extracted. ${ }^{19}$ The reason for the focus on China rather than India in this book is due to the vigorous external relations policy pursued by China in recent years; as seen, for example, in the establishment of the Chinese-led Asian Infrastructure Investment Bank (AIIB), and the development of the China-Pakistan Economic Corridor from Kashgar in Xinjiang, China to Gwadar in Pakistan on the Arabian Sea, via Pakistan-administered Kashmir. Both of these initiatives have potential to significantly impact upon the environment of the Third Pole, and are analysed in Chapter 5.

In relation to the existing subregional environmental regimes, the first and second outlined in Chapter 2 (southwest Asia) are the Arabian Gulf/Gulf of Oman Convention, ${ }^{20}$ and the Red Sea and Gulf of Aden Convention, ${ }^{21}$ which are focused primarily on coastal and marine issues, the latter also concerning the pan-region of Africa and Asia. There are eight western Asian Parties to the first: Bahrain, Iran, Iraq, Kuwait, Oman, Qatar, Saudi Arabia and the United Arab Emirates. There are now four western Asian Parties to the second: Jordan, Palestine, Saudi Arabia and Yemen. There are also two African Parties to the second: Sudan and Somalia. Saudi Arabia is therefore a Party to both of these agreements.

In Chapter 3 (central Asia) the third regime considered is shaped by the Caspian Sea Convention, ${ }^{22}$ which concerns the pan-region of

18 For an overview of the role of both powers, see: Christopher Ogden, China and India: Asia's Emergent Great Powers (Polity, Cambridge, 2016) in press; Christopher Ogden, New South Asian Security: Six Core Relations Underpinning Regional Security (Orient Black Swan, 2016); M Sornarajah and Jiangyu Wang, China, India and the International Economic Order (Cambridge University Press, Cambridge, 2010); and in relation to the NGO advocacy role, see Neda A Zawahri and Oliver Hensengerth, 'Domestic Environmental Activists and the Governance of the Ganges and Mekong Rivers in India and China' (2012) 12 International Environmental Agreements 269-298.

19 Simon Marsden, 'Environmental Assessment of Cross-Border Development: China and the Third Pole' (2016) 18(1) Journal of Environmental Assessment Policy and Management 1650009-1-1650009-21.

20 Regional Convention for Cooperation on the Protection of the Marine Environment from Pollution (Kuwait, 24 April 1978), in force 1 July 1979.

21 Regional Convention for the Conservation of the Red Sea and Gulf of Aden (Jeddah, 1982), ECOLEX B7 p. 982:13, in force 20 August 1985.

22 Framework Convention for the Protection of the Marine Environment of the Caspian Sea (Tehran, 4 November 2003) 44 ILM 1 (2005), in force 12 August 2006. 
southwest, ${ }^{23}$ central and northern Asia. This applies to the 'Caspian Littoral States' of Azerbaijan, Iran, Kazakhstan, Turkmenistan and Russia; all of these are southwest or central Asian states or have territory that extends into northern - or indeed eastern - Asia (Russia). The fourth regime examined is constituted collectively by the water resource arrangements for the Aral Sea: the Joint Management and Conservation of Interstate Water Resources Agreement, ${ }^{24}$ the International Fund for Saving the Aral Sea Agreement, ${ }^{25}$ and the Interstate Commission for Water Coordination Statute. ${ }^{26}$ The Aral Sea lies to the east of the Caspian Sea between Kazakhstan and Uzbekistan, which are Parties to these bilateral arrangements. The fifth regime outlined is the Environmental Protection for Sustainable Development Convention; ${ }^{27}$ this is not in force but has been signed by each of the five central Asia states: Kazakhstan, Kyrgyzstan, Tajikistan, Turkmenistan and Uzbekistan. Kazakhstan and Turkmenistan are therefore Parties to the first of these agreements and signatories to the second.

In Chapter 4 (southeast Asia) the sixth of the regimes analysed is the Mekong Agreement, ${ }^{28}$ which has been ratified by Cambodia, Laos, Thailand and Vietnam; China and Myanmar additionally became Dialogue Partners in 1996. The seventh is the Association of Southeast Asian Nations (ASEAN) Conservation Agreement, ${ }^{29}$ and related Centre for Biodiversity Agreement; ${ }^{30}$ and the eighth is the ASEAN Haze Pollution

23 The political geography of the Middle East has connections both with Africa and Asia, and appears unsettled.

24 Agreement on Cooperation in the Field of Joint Management and Conservation of Interstate Water Resources (Almaty, 18 February 1992), <http:// www.caee.utexas.edu/prof/mckinney/papers/aral/agreements/ICWC-Feb18-1992. pdf $>$ accessed 27/1/16.

25 Agreement about the Status of the International Fund for Saving the Aral Sea (Ashgabat, 9 April 1999).

26 Statute of the Interstate Commission for Water Coordination of Central Asia (Almaty, 18 September 2008).

27 Framework Convention on Environmental Protection for Sustainable Development in Central Asia (Ashgabat, 22 November 2006) TRE-143806, not in force, <http://www.ecolex.org/server2.php/libcat/docs/TRE/Full/En/TRE-143 806.pdf $>$ accessed 20/11/14.

28 Agreement on the Cooperation for the Sustainable Development of the Mekong River Basin (Chiang Rai, 5 April 1995), unreported, in force 5 April 1995.

29 Association of South East Asian Nations, Agreement on the Conservation of Nature and Natural Resources (9 July 1985) 15 EPL 64, not in force.

30 Agreement on the Establishment of the ASEAN Centre for Biodiversity (Capitals of each member state, 2005). 
Agreement. ${ }^{31}$ While the Conservation Agreement is not in force and the Haze Pollution Agreement is, both have been approved by all or most of the ASEAN nations, who have also recently approved the Centre for Biodiversity Agreement.

In Chapter 5 (south and east Asia), existing governance arrangements are outlined further to the South Asia Co-operative Environment Programme (SACEP), and the South Asian Association for Regional Cooperation (SAARC). SAARC was formed by Charter 1985 by the following states: Bangladesh, Bhutan, India, Maldives, Nepal, Pakistan and Sri Lanka; Afghanistan joined later. ${ }^{32}$ SACEP has the same membership. The latter has produced three relevant agreements, although these do not amount to an environmental regime, mainly because the environment is not the primary focus or detail is missing. Both these institutions and the agreements produced are however outlined because of their relevance to the establishment of a regime for the Third Pole. The agreements are the Environmental Cooperation Convention, ${ }^{33}$ the Rapid Response to Natural Disasters Agreement, ${ }^{34}$ and the Energy Cooperation (Electricity) Agreement. ${ }^{35}$ Other mechanisms of note are either bilateral (Indus Waters Treaty), ${ }^{36}$ or without hard law underpinnings (the Malé Air Pollution Declaration), ${ }^{37}$ and the South Asian Regional Seas Programme. ${ }^{38}$

31 Association of South East Asian Nations, Agreement on Transboundary Haze Pollution (Kuala Lumpur, 10 June 2002), unreported, in force 2003.

32 Charter of the South Asian Association for Regional Cooperation (Dhaka, 18 December 1985).

33 SAARC Convention on Cooperation on Environment (Thimphu, 28-29 April 2010), unreported, in force 23 October 2013.

34 SAARC Agreement on Rapid Response to Natural Disasters (Maldives, 10-11 November 2011), unreported, not in force at November 2014, five states had ratified.

35 SAARC Framework Agreement for Energy Cooperation (Electricity) (Kathmandu, 27 November 2014), unreported, not in force.

36 Indus Waters Treaty between the Government of India and the Government of Pakistan (Karachi, 19 September 1960), 419 UNTS 126, in force 1 January 1961.

37 Malé Declaration on Control and Prevention of Air Pollution and its Likely Transboundary Effects for South Asia, 1998. See: <http://www.rrcap.ait. asia/male/Pages/Agreement.aspx $>$ accessed 28/1/16.

$38<$ http://www.unep.org/regionalseas/programmes/nonunep/southasian/default. asp $>$ accessed 8/6/2016. 
The ninth regime is made up of the Tumen Agreements, ${ }^{39}$ which were originally signed by North Korea, China and Russia, and later by South Korea and Mongolia. As with the South Asian Regional Seas Programme, the East Asian Regional Seas Programme is also not considered to constitute a regime as such because it lacks the treaty underpinning found in the western and central Asian arrangements. It is therefore only briefly outlined, together with the air pollution measures for northeast Asia. Similarly, the transboundary environmental governance for the jurisdictions of the Pearl River Delta 'Region' in southern China are noted but not discussed in detail. ${ }^{40}$

Chapter 5 finally focuses on the Third Pole as an additional tenth regime connecting south Asia (mainly the Himalayas) with east Asia (the Tibetan Plateau). Furthermore, there are connections with central Asia given the western extent of this high-altitude terrain. Based on the application of the developed analytical framework, the objective of the book is therefore to provide a comprehensive, comparative evaluation of the existing subregional environmental agreements in Asia, with a view to drawing lessons for other Asian subregions (or, indeed, globally), which do not have such a regime. The focus on the Third Pole as an additional regime emphasizes the links between environment, water and climate governance in particular, all of which have major transboundary dimensions. Based on the analysis of the existing regimes, the book therefore proposes a preliminary governance framework for the Third Pole, with a view to advancing the limited legal and policy discourse to date, and to gaining recognition and support for more detailed elaboration in the future.

\section{RESEARCH QUESTIONS AND METHODOLOGY}

The research approach is primarily a documentary analysis, informed where possible by informal, semi-structured interviews with experienced

39 Agreement on the Establishment of the Tumen River Area Development Coordination Committee (New York, 6 December 1995), unreported, in force 6 December 1995; and Agreement on the Establishment of the Consultative Commission for the Development of the Tumen River Economic Development Area and Northeast Asia (New York, 6 December 1995), unreported, in force 6 December 1995.

40 See Marsden, above n. 17, 2010, 2011 and 2013. 
scholars. Documents evaluated include treaty texts and associated guidance, and materials produced by meetings of the Parties (MOPs); consultancy reports delivered in response to information needs identified by existing regimes; other international materials of a comparative nature, including multilateral and regional environmental regimes; and secondary source materials from scholars and non-governmental organizations (NGOs) closely connected with the regimes under review. From a review of the information obtained, including many case studies of the subregions' evaluation, the analytical framework was developed in ordered to assist with answering the research questions. Key questions were decided upon based on the findings of a review of the literature of environmental regimes and subregions. Other than the final two - transferability and the role of China in relation to the Third Pole, which will be answered in the concluding section of Chapter 5 - each of the others (including the role of China in connection with the other subregions), are answered in the concluding sections to Chapters 2-4. The research questions are as follows:

- What institutional arrangements are in place?

- What objectives and principles guide action?

- What are the key provisions?

o Are these institutional arrangements, objectives, principles and provisions effective?

- How can effectiveness be measured? o In particular, what evidence of practice is there?

- Are more specialized arrangements present?

o In particular, to what extent are reporting mechanisms and compliance controls included?

- Are the institutional arrangements, objectives, principles and provisions transferable, or capable of transfer?

- What is China's role presently in relation to the environmental regimes?

o What can it potentially be in the future, particularly in relation to the Third Pole?

\section{FRAMEWORK FOR ANALYSIS}

As indicated in the overview above, the analysis framework is based on international best practice, with reference to the approach of MEAs and 
as reviewed by international environmental law scholars in particular. ${ }^{41}$ From the literature it is clear that basic components must include the environmental duties found in general international law (no harm, cooperation, equitable utilization), environmental principles (precaution, polluter pays, etc.), substantive obligations, and treaty mechanisms to avoid and resolve disputes. However, compliance and enforcement, the acknowledged weakest elements in international environmental law, have been given particular emphasis in recent environmental treaties, as noted by the UNEP guidance in relation to compliance and enforcement. UNEP's Division of Environmental Law and Conventions has furthermore focused on strengthening links and synergies between MEAs as a means of promoting a systematic approach to coordination, and its guidance on compliance and enforcement remains very relevant today. ${ }^{42}$ The need to include all such elements in any environmental regime, whether global or regional in application, is hence essential.

With respect to compliance and enforcement in the Asian context, however, it has been very clearly found that in many instances there has been a reluctance to accept the need for binding agreements at all, or to interfere in the environmental practices of other states. ${ }^{43}$ This is in part as

41 In addition to those outlined above n. 1, see also Adam Byrne, 'The 1979 Convention on Long-Range Transboundary Air Pollution: Assessing its Effectiveness as a Multilateral Environmental Regime after 35 Years' (2015) 4(1) Transnational Environmental Law 37-67, 39-40, distinguishing between legal (what is complied with), institutional (a cooperative approach) and normative (contribution towards justice, fairness and participation) effectiveness; Timo Koivurova, Pamela Lesser, Sonia Bickford, Paula Kankaanpää and Marina Nenasheva, Environmental Impact Assessment in the Arctic (Edward Elgar Publishing, Cheltenham, 2016) 15, regarding 'best practice research' focused upon what is implemented, and/or has been shown to work; and Timo Koivurova, Paula Kankaanpää and Adam Stępień, 'Innovative Environmental Protection: Lessons from the Arctic' (2015) 27 Journal of Environmental Law 285-311, 287-288 with respect to the need for organizational learning and adaptive governance.

42 See Carl Bruch and Elizabeth Mrema, Manual on Compliance with and Enforcement of Multilateral Environmental Agreements (UNEP, Nairobi, 2006), available at: <http://www.unep.org/delc/MEAImplementationSupport/tabid/544 01/Default.aspx $>$ accessed 10/3/15. UNEP is not however without critics, see: DC Esty, 'Breaking the Environmental Law Logjam: The International Dimension' (2008) 17(1) N.Y.U. Environmental Law Journal 836, 846-848.

43 Lorraine Elliot, 'East Asia and Sub-Regional Diversity: Initiatives, Institutions and Identity', in L Elliott and S Breslin (eds), Comparative Environmental Regionalism (Routledge, Abingdon, 2011) 60. 
a result of the difference in Asian values ${ }^{44}$ or what has become known as the 'Asian', or 'ASEAN way'. ${ }^{45}$ Indeed the importance of context is a readily acknowledged constraint upon any legal or other transplant. ${ }^{46}$ The question of whether common standards and indicators are able to be applied to these different contexts has therefore been an issue for some time, whether used to evaluate environmental performance specifically, or notions of what amounts to good regional governance in general; ${ }^{47}$ this is acknowledged by Best in the development of a set of parameters to evaluate the quality of governance in systems of regional cooperation or integration. ${ }^{48}$

Regime effectiveness is considered in more detail in a section below, and, as will be seen in the chapters that follow, the need for contextual perspectives remains to a considerable extent today. Indeed, the growing strength of a resource-hungry China in the region has been a cause for significant concern. ${ }^{49}$ Dispute settlement in international fora for example is therefore frequently replaced by more cooperative approaches, ${ }^{50}$ particularly where capacity may be lacking. As an alternative, the provision of assistance in order to avoid disputes is also likely to gain support and

44 Roda Mushkat, International Environmental Law and Asian Values: Legal Norms and Cultural Influences (UBC Press, Vancouver, 2004)

45 KL Koh and NA Robinson, 'Strengthening Sustainable Development in Regional Inter-Governmental Governance: Lessons from the "ASEAN Way", (2002) 6 Singapore Journal of International and Comparative Law 640-682; see also Mark Beeson, 'The Coming of Environmental Authoritarianism' (2010) 19(2) Environmental Politics 276-294.

46 Koivurova et al., 2016, above n. 41. In relation to EIA, context and effectiveness, see also Thomas Fischer (ed), Environmental Assessment: Critical Concepts in Built Environment (Routledge, Abingdon, 2015) volume 4, Environmental Assessment Effectiveness, Chapters 54-72, including Chapter 55, originally published as Simon Marsden, 'Importance of Context in Measuring the Effectiveness of Strategic Environmental Assessment' (1998) 16(4) Impact Assessment and Project Appraisal 255-266.

47 Edward Best, 'Regional Integration and (Good) Regional Governance: Are Common Standards and Indicators Possible?' UNU-CRIS Working Papers, O-2004/6 (United Nations University, 2004) 1-45.

48 Edward Best, 'The Assessment of Regional Governance: Principles, Indicators and Potential Pitfalls' UNU-CRIS Working Papers, W-2008/10 (United Nations University, 2008) 1-27.

49 Simon Webb, 'ASEAN Says Seriously Concerned About Rising South China Sea Tensions', Reuters, 27 February 2016.

50 Simon Chesterman, 'The International Court of Justice in Asia: Interpreting the Temple of Preah Vihear Case' (2015) 5(1) Asian Journal of International Law 1-6. 
ensure that the objectives and outcomes of environmental agreements are fulfilled. The more modern approach of many of the UN Economic Commission for Europe (UNECE) agreements for example, in incorporating provision for NIRs and NCPs, has been found to be a positive support for environmental compliance in Asia. ${ }^{51}$

The question of effectiveness in relation to environmental regimes has been explored at length in the international relations and, to a lesser extent, international political economy literatures, and is also an important criterion for any analysis framework. However, previous subregional comparative analyses have not accorded significant weight to this, in recognition of the fact that 'It would be difficult to evaluate the effectiveness of these cooperative programmes/mechanisms against any reasonably acceptable measure of effectiveness' ${ }^{52}$ As an alternative, Kato therefore considered measures of achievement towards goals, objectives and targets, including action plans and projects; ${ }^{53}$ this approach will also be employed in this book. The use of indicators has also been deployed recently in an Asian context, for example by ASEAN, where they have been used in the context of global administrative law. ${ }^{54}$ It was found that the consensus approach to decision making prevailed, and that:

Any attempt to incorporate the measurement of civil or political standards that lean towards a particular political ideology, into the ASEANstats indicators, would have met with strong disagreement and opposition. Further, such an attempt could be seen as a form of interference in the internal affairs of other states: for example, the measurement of press freedom might have been viewed by the more authoritarian states within ASEAN as advocating a more liberal model of governance. It is not unheard of for such political differences and contestation to suppress the expansion of an indicator, and this may thus

51 Marsden and Brandon, above n. 9. With respect to water, see also Simon Marsden, 'The Helsinki Water Convention: Implementation and Compliance in Asia' (2015) 20(2) Nordic Environmental Law Journal 119-129; and Attila Tanzi, 'Regional Contributions to International Water Cooperation: The UNECE Contribution', in Laurence Boisson de Chazournes, Christina Leb and Mara Tignino (eds), International Law and Freshwater: The Multiple Challenges (Edward Elgar, Cheltenham, 2013).

52 Kazu Kato, 'An Analytical Framework for a Comparative Study of Subregional Environmental Programmes in Asia', in Kato and Takahashi, above n. 14,5 .

53 Ibid.

54 Matthew Koh, 'Indicators in the ASEANstats Statistical Regime: A Case-Study on the Need for Accountability, Participation, and Transparency in International Governance by Indicators' (2016) 6(1) Asian Journal of International Law 159-191. 
provide a reason for the unexplained, lopsided focus of the ASEANstats indicators. ${ }^{55}$

The remainder of this chapter will consider environmental regimes and subregimes, their effectiveness, and the Asian context for their operation, before ending with detailed chapter summaries.

\section{REGIMES AND SUBREGIMES}

A regime is a form of government or governance and combines law, politics and institutions. In more modern formulations, stakeholders may be both government and non-government organizations in the states concerned. A common dictionary definition for a regime is a 'set of rules, cultural or social norms that regulate the operation of a government or institution and its interactions with society' ${ }^{56}$ Although many dictionary definitions emphasize an authoritarian aspect, this is not necessarily seen in practice. However in the Asian environmental governance context, it has been recently argued that environmental authoritarianism may be better placed to deal with environmental issues than democratic governance, largely because of the pressures of population and development. ${ }^{57}$ The word regime is also commonly used in international relations, politics and law to refer to more 'specialized arrangements', and often involves questions of sovereignty or jurisdiction.

Young comments: 'International regimes ... are more specialized arrangements that pertain to well-defined activities, resources, or geographical areas and often involve only some subset of the members of international society'. ${ }^{58}$ These specialized arrangements for institutional components for example, may include MOPs, secretariat and working group functions, together with compliance procedures. Opportunities for other stakeholders to be involved, such as NGOs, individuals and the public, are also an important part of modern environmental regimes, in recognition of the fact that conventional interpretations of environmental governance based on regime theory are evolving, and 'critiques of mainstream approaches may yet help to articulate a pluralist account of global governance in which non-state actors play a more

\footnotetext{
55 Ibid, 177, footnote removed from quotation.

$56<$ http://en.m.wikipedia.org/wiki/Regime> accessed 10/3/15.

57 Beeson, above n. 45, 276-294.

58 Oran R Young, International Cooperation: Building Regimes for Natural Resources and the Environment (Cornell University Press, Ithaca NY, 1989) 13.
} 
important part'.59 Razzaque also comments in relation to the World Summit on Sustainable Development (WSSD): 'One of the major outcomes of the WSSD in 2002 was the emphasis on regional implementation though partnership between governments and civil society'.60 And Söderbaum and Granit continue: 'There is also an emphasis on the role of stakeholders other than simply governments and regional organisations, which is considered important for recognising the multiplicity of relationships among countries, many of which involve the private sector and civil society' ${ }^{61}$

Environmental regimes have been studied by international relations scholars for the last 25 years or more. ${ }^{62}$ Research has distinguished between comprehensive environmental regimes which typically include all aspects of environmental control, and specific sub-environmental regimes which focus on a particular aspect, such as biodiversity conservation. ${ }^{63}$ Kotzé comments: 'Regimes are among the institutional constructs that society has devised to respond to global environmental problems. They play a fundamentally important role in global (environmental) governance'. ${ }^{64}$ In an international law context, framework agreements often provide for a comprehensive regime, which is then elaborated in more detail in protocols relevant to specific areas. As indicated above, regulation of the Caspian Sea is of this type, with a reasonably comprehensive treaty then detailed in a number of protocols which include both biodiversity conservation and environmental impact assessment (EIA).

Another example is specific governance for biodiversity conservation, which many be applied at either the multilateral, regional, or subregional levels. Within a state, national, regional and local efforts may in turn mirror global governance frameworks in order to implement international obligations; regional entities like the EU may also be required to

59 Newell, above n. 10, 509.

60 Jona Razzaque, Environmental Governance in Europe and Asia: A Comparative Study of Institutional and Legislative Frameworks (Routledge, Abingdon, 2013) 35.

${ }^{61}$ F Söderbaum and J Granit, The Political Economy of Regionalism: The Relevance for International Waters and the Global Environment Facility (Global Environment Facility, Washington DC, 2014) 23.

62 Litta, above n. 5, 49.

63 Kotzé (2012), above n. 13, 133.

64 Ibid, 126. 
implement international obligations. ${ }^{65}$ Within Asia, MEAs include the Biodiversity Convention ${ }^{66}$ and the Climate Change Convention. ${ }^{67}$ Regional measures include the issue-focused treaties of the UNECE, the only UN Regional Commission to have produced any environmental agreements, ${ }^{68}$ which includes the Helsinki Water Convention. ${ }^{69}$ Subregional efforts include the agreements analysed in this book for the protection of the Arabian Gulf and Gulf of Oman, the Red Sea and Gulf of Aden, the Caspian Sea, the Mekong River Basin, and, to a lesser degree the Tumen region. They also include the conservation and haze pollution measures taken by ASEAN, and other applications by SACEP and SAARC. While formal regimes are prioritized because they are underpinned by legal mechanisms that typically apply to more than two states, other emerging regimes are also considered. These include other UNEP Regional Seas arrangements (in particular for south and east Asia), and air pollution measures in south and northeast Asia. In all cases, the following conclusion is generally true:

In sum then, the broader environmental regime and its sub-regimes provide the opportunity and means for collective global action and a concerted regulatory response to environmental issues through various state and nonstate actors and by means of a multitude of normative arrangements including many laws. ${ }^{70}$

65 See for example Simon Marsden, 'Invoking Direct Application and Effect of International Treaties by the European Court of Justice: Implications for International Environmental Law in the European Union' (2011) 60(3) International and Comparative Law Quarterly 737-757, reprinted in JE Viñuales and E Lees (eds) Environmental and Energy Law, part of a three-volume collection, The International Library of Law and Environment (Edward Elgar, Cheltenham, in press).

66 Convention on Biological Diversity (Rio de Janeiro, 22 May 1992), 31 ILM 822, in force 29 December 1993.

67 United Nations Framework Convention on Climate Change (Rio de Janeiro, 9 May 1992), 1771 UNTS 107, in force 21 March 1994.

68 Marsden and Brandon, above n. 9.

69 Attila Tanzi, Owen McIntyre, Alexandros Kolliopoulos, Alistair RieuClarke and Remy Kinna (eds), UNECE Convention on the Protection and Use of Transboundary Watercourses and International Lakes: Its Contribution to International Water Cooperation (Brill Nijhoff, Leiden, 2015); Tanzi (2013), above n. 51; and in an Asian context, see Marsden above n. 51.

70 Kotzé, above n. 13, 134. 


\section{REGIME EFFECTIVENESS}

Litta traces the history of environmental regime analysis, which 'evolved as a response to mounting international concern about threats to environmental quality since the 1970 s' ${ }^{71}$ Many studies have focused on the effectiveness of environmental regimes, pointing to common features ${ }^{72}$ which, in relation to issue specific regimes, 'sometimes play a decisive role in ameliorating environmental problems'. Common features of effective regimes, for example, are that benign problems are easier to solve than malign ones; that well understood problems are easier to solve than those that are clouded by uncertainty; and that the greater the problem-solving capacity and favourable political context, the greater likelihood of success. ${ }^{73}$ Underdal supports these findings, evaluating effectiveness in accordance with two general propositions: the character of the problem itself, which may be easier to solve if it is intellectually less complicated or politically benign; and the problem-solving capacity, which will be greater if powerful institutional tools are available or because greater skill or energy is present to address it. ${ }^{74}$ Litta considers the question of effectiveness at length in recent scholarship, asking the pertinent sub-questions as follows:

Is it compliance with the regime rules? Is it the level of implementation of regulations stipulated by the regime? Is it the attainment of goals stipulated in the regime rules? Is it the achievement of desired outcomes with the least costs? Is it the peaceful agreement between stakeholders with different preferences? Is it the achievement of values [such] as fairness, justice, stewardship and equal participation? Or is a regime only effective if the quality of the environment is improved? ${ }^{75}$

It is of course all of these things, and the issue is more one of focus, given the practicalities of addressing them all. It is specifically a matter of disciplinary focus; dealing with the last question in particular requires an empirical dimension which in the environmental context is more likely

\footnotetext{
71 Litta, above n. 5, 48.

72 See for example, Young (1999), above n. 1; Miles et al. (2002), above n. 1; Breitmeier et al. (2006), above n. 1; Kotzé (2012), above n. 13.

73 Miles et al., above n. 1, 'Introduction'.

74 Arild Underdal, 'One Question, Two Answers', in EL Milev, A Underdal, S Andresen, J Wettestad, JB Skjærseth and EM Carlin (eds), Environmental Regime Effectiveness: Confronting Theory with Evidence (MIT Press, Cambridge, 2002) 3-45.
}

75 Litta above, n. 5, 50. 
to be considered by scientists than international law or relations scholars. This book has a more typical normative focus, in line with the comment by Newell that: 'It is not a caricature to suggest that environmental governance for many scholars of IR [International Relations] continues to be reduced to the study of international environmental law and the institutions that produce it and enforce it ...' ${ }^{76}$

\section{ASIA AS HOME TO MANY ENVIRONMENTAL REGIMES AND SUBREGIMES}

Asian states are Parties to numerous MEAs, including those highlighted above, and collaborate via these global regimes in addressing transboundary and other environmental challenges. As seen also above, the interest in regions and subregions has grown hugely over recent decades; this is a global phenomena with regional organizations found across the continents, and with inspiration drawn from the EU in particular, leading to significant EU/Asian comparative research. ${ }^{77}$ Organizations in Asia considered in this book include the work of specifically environment-focused UN bodies such as UNEP, MDBs/IFIs such as the ADB, and economic cooperation bodies such as ASEAN; the latter two, as emphasized, also focus heavily on environmental concerns, in part because there is an economic cost to this. Gochhayat, in a recent study with special reference to India, provides a comprehensive introduction to notions of regionalism and subregionalism. The author begins with a definition which distinguishes between two very different meanings of regionalism:

At the international level, regionalism refers to transnational cooperation to achieve a common goal or resolve a shared problem or it refers to a group of countries, such as Western Europe, the Western Balkans, or Southeast Asia, that are linked by geography, history or economic features. Used in this sense, regionalism refers to attempts to reinforce the links between these countries ...

The second meaning of the term ... regionalism refers to a process in which sub-state actors become increasingly powerful and independent of the state: power devolves from the central state to regional governments within it. In

\footnotetext{
76 Newell, above n. 10, 508 [original emphases].

77 See for example, Razzaque, n. 60; also Jörg Balsiger and Aysun Uyar (eds), Comparing Regional Environmental Governance in East Asia and Europe: Proceedings (Research Institute for Humanity and Nature, Kyoto, 2013); and Tavares, above n. 3, who considers the notion of 'inter-regionalism' or crossregionalism (at 19-20).
} 
other words, it refers to a territory that is located within, or sometimes across the borders of a nation state. ${ }^{78}$

The focus of this book is upon the first of these meanings, while recognizing the relationship between them that comes from greater levels of integration leading to calls for more autonomy within, or indeed, separation from such groupings. If the EU is the best example of the former meaning, it also admirably demonstrates the latter. Increased integration has produced calls from the UK to renegotiate terms of the treaties upon which the EU is founded, as well as calls to leave the EU; if this is to occur, there are however genuine concerns about the effect on the environment. ${ }^{79}$ At a different level, calls for autonomy by regions and subregions within member states of the EU - such as Scotland within the UK, ${ }^{80}$ and Catalonia within Spain ${ }^{81}$ - illustrate their autonomous claims and how regionalism and subregionalism are fluid concepts, which may or may not be realized. ${ }^{82}$

The UN has emphasized the importance of regions and subregions in the work of its Statistics Division, ${ }^{83}$ Environment Programme, ${ }^{84}$ and via its Regional Commissions. ${ }^{85}$ In 1999, the Statistics Division developed a system of macro-geographical (continental) regions, subregions and other selected economic groups to report advances towards achieving the Millennial Development Goals (MDGs) globally. ${ }^{86}$ The UN Geoscheme

78 A Gochhayat, 'Regionalism and Sub-Regionalism: A Theoretical Framework with Special Reference to India' (2014) 8(1) African Journal of Political Science and International Relations 10.

79 Fiona Harvey, 'Brexit Would Damage UK Environment, Say Experts', The Guardian, 27 January 2016; for a contrary view, see George Monbiot, 'Why the EU's Increasing Failure to Protect Nature Means I May Vote No', The Guardian, 10 July 2015.

80 Ruth Wishart, 'The EU Referendum is Already Following the Scottish Playbook, Project Fear 2.0', The Guardian, 26 February 2016; Severin Carrell and Libby Brooks, 'Nicola Sturgeon: Second Scottish Independence Poll Highly Likely', The Guardian, 25 June 2016.

81 Giles Tremlett, 'Catalonia's Separatist Government will Struggle to Break Stalemate with Spain', The Guardian, 11 January 2016.

82 Note the position with respect to Hong Kong; SC Yeung, 'Is HK Independence a Mainstream Thought Among the Youth?' Economic Journal Insight, 24 February 2016.

$83<$ http://unstats.un.org/unsd/default.htm> accessed 10/3/15.

$84<$ http://www.unep.org/> accessed 10/3/15.

85 Above $n$ 7.

86 <http://millenniumindicators.un.org/unsd/methods/m49/m49regin.htm\# asia $>$ accessed 10/3/15. In connection with this, see Emanuela Maria Cavaleri, 
distinguishes these regions and subregions into 'Central Asia', 'Eastern Asia', 'Southern Asia', 'South-Eastern Asia' and 'Western Asia', each identified with a numerical code and composed of states as indicated. ${ }^{87}$ Some of the divisions and compositions may appear inaccurate geographically, ${ }^{88}$ ethnically/culturally, ${ }^{89}$ or are indeed politically controversial. ${ }^{90}$

In 2003, the Asia Pacific region of UNEP held its first Subregional Environmental Policy Dialogue (SEPD) meeting in Beijing; these have been held annually since. UNEP is the Secretariat for the annual SEPD, facilitating the preparation of background documentation and providing logistical support for/in liaison with the host government, as well as documentation of the meeting records and recommendations. The functions of UNEP are therefore to: provide a forum for consolidating Asia-Pacific views on global environment issues; deliver regional inputs to MEAs and global events such as UNEP's Governing Council and the Global Ministerial Environmental Forum; advise on critical and emerging environmental issues in Asia and the Pacific; and provide policy guidance for the effective implementation of programmes in Asia and the Pacific. There are five subregions of the UNEP Asia Pacific region: central Asia, south Asia, southeast Asia, northeast Asia and the south Pacific; western Asia is also a focus of UNEP efforts, with various institutional mechanisms established; finally, the Regional Seas Programme is often noted as one of its major achievements.

'The Post-2015 UN Development Framework: Perspectives for Regional Involvement' UNU-CRIS Working Papers, W-2014/12 (United Nations University, 2012) $1-28$.

87 <http://unstats.un.org/unsd/methods/m49/m49regin.htm\#asia> accessed 10/3/15.

88 Russia is not included as an Asian state, despite the majority of its territory (east of the Urals) constituting North Asia, for which there is no category; Turkey by contrast is included in Western Asia, despite (admittedly very small) parts of its territory being within Europe. Iran is also included within Southern Asia not Western Asia.

89 Cyprus, Israel and Georgia are included in Western Asia despite their close involvement/association with Europe. Northern Cyprus, with the greatest cultural and ethical claims to being part of Western Asia, is a Turkish Republic not recognized by the international community.

90 The Hong Kong and Macau Special Administrative Regions are both separately included in Eastern Asia but not Taiwan. Furthermore, the State of Palestine is now included in Western Asia alongside Israel; the existence of both is contested by various states. 
There are five UN regional commissions, of which three are active in environmental policy making in Asia: the Economic and Social Commission for the Asia Pacific (UNESCAP), the Economic and Social Commission for Western Asia (UNESCWA), and the UNECE. The UNECE Environmental Policy is the oldest and has promoted sustainable development further to Agenda 21; a Committee was formed from senior advisors to ECE governments in 1971, with the terms of reference from the 62nd session in 2007 including a focus on the Caucasus and central Asia. In relation to UNESCAP, a 1st Ministerial Conference on Environment and Development was held in 1985, which has been held every five years since. Regarding UNESCWA, a Regional Coordination Mechanism for Arab States held its 20th Meeting in December 2014.

The UNECE is particularly relevant because it has a large number of Asian members; ${ }^{91}$ as indicated, it is also the only one of the regional commissions to have produced any environmental treaties (5) or related protocols (12), ${ }^{92}$ several of which have been inspirational for the subregional regimes in their own development. For example, the EIA Convention $^{93}$ has been a model for the EIA Protocol ${ }^{94}$ under the Caspian Sea Convention and is assisting states Parties to the Mekong and Tumen regimes in elaborating more detailed measures; and the Public Participation Convention ${ }^{95}$ is also playing a role in considering best practice requirements under the Caspian Sea and Mekong arrangements. ${ }^{96}$

91 Turkey, Israel, Russia, Georgia, Armenia, Azerbaijan, Kazakhstan, Kyrgyzstan, Tajikistan, Turkmenistan and Uzbekistan.

92 Wiek Schrage, Keith Bull and Albena Karadjova, 'Environmental Legal Instruments in the UNECE Region' (2008) 18(1) Yearbook of International Environmental Law 3-31; and Marsden and Brandon, above n. 9.

93 Convention on Environmental Impact Assessment in a Transboundary Context (Espoo, 25 February 1991) 30 ILM (1991) 802, in force 27 June 1997.

94 Protocol on Environmental Impact Assessment in a Transboundary Context to the Framework Convention for the Protection of the Marine Environment of the Caspian Sea, 2012; see also associated EIA Guidelines.

95 Convention on Access to Information, Public Participation in DecisionMaking and Access to Justice in Environmental Matters (Aarhus, 25 June 1998) 2161 UNTS 447, in force on 30 October 2001. This is often known as the 'Aarhus Convention'.

96 With respect to the former, see Framework Convention for the Protection of the Marine Environment of the Caspian Sea, Conference of the Parties Fifth Meeting [29-30 May 2014, Ashgabat] Turkmenistan, Items 5 and 12 of the Provisional Agenda, Recommendations and Analysis Based on the Comments by the Aarhus Convention Secretariat on Public Participation under the Tehran Convention, Note by the Interim Secretariat, TC/COP5/INF.6. 
The distinction between UN regions and subregions as drawn by the Statistics Division, UNEP and the Regional Commissions highlights the very high degree of regionalism and subregionalism within Asia. The ADB commented extensively upon this in a 2008 study, which was focused on economic development of Asia's regions and subregions. Not surprisingly, this gave minimal consideration to environmental issues, although energy demands and implications, and impacts upon water and air, were noted. ${ }^{97}$ It commented: "Asian regionalism is the product of economic interaction, not political planning' ${ }^{98}$ This recognized how, initially at least, all the drivers were economic, in more recent times to meet the challenges of the 1997/98 Asian financial crisis. The geographical scope of the report is furthermore limited to the 16 economies of the ASEAN states, India and others in east Asia, with west, central, north (Russia in particular) and south Asia (except India) excluded.

With a focus on the political economy of regionalism, other authors have considered environmental effects in more detail, for example the relevance for international waters. ${ }^{99}$ Söderbaum and Granit comment for instance that "Regionalism" refers to the common objectives, values and identities that lead to region-formation and regional cooperation within a given geographical area. It often leads to the creation and development of regional institutions and regional governance frameworks in order to shape and regulate collective action'. ${ }^{100}$ Other approaches to regionalism include: by geography, for example the distinction between greater China (including Taiwan) and mainland China, what is considered part of northeast Asia, and also north Asia; by geology, for example the 'Third Pole' (Himalayas/Tibetan Plateau); by eco-regions, for example river basins, such as the Mekong; by politics, economics, or security, for example the role of ASEAN and the Eurasian Economic Community; by religion, consider the Middle East/western Asia; and, finally, by language and culture - consider Cantonese, spoken by people across southern China despite jurisdictional divides. ${ }^{101}$

\footnotetext{
97 Asian Development Bank, above n. 4, 207-210.

98 Ibid, 26.

99 Söderbaum and Granit, above n. 61.

100 Ibid, 7 [original emphasis].

101 Note that ironically 'Canton' is the generic name also for Swiss subregions.
} 


\section{DETAILED CHAPTER SUMMARIES}

By way of an overview, following this Chapter 1, Chapters 2-5 will analyse the subregional agreements in Asia - grouped into southwest (Chapter 2), central (Chapter 3), southeast (Chapter 4), and south and east (Chapter 5) Asia. As will be seen in the latter chapter, the development of subregional agreements is much less developed in east and south Asia, and it is for these subregions that a proposed regime for the Third Pole is considered. Technically encompassing territory in east Asia (the Tibetan Plateau), as well as the mountains in the south Asian states, the Third Pole is a cross-subregion in the same way that the First Pole (the Arctic), is a cross-region (north America, northern Europe, north Asia).

The role of China in east Asia and more generally is also considered in Chapter 5, following analysis of its role in the other subregions outlined at the end of the preceding chapters. This role is either as a Party or Dialogue Partner, international lender or developer. Apart from the questions answered in Chapters 2-4, Chapter 5 also contains other conclusions in response to the research questions outlined above, recommendations and consideration of future research directions. For each of the regimes considered in Chapters 2-4, and where possible, also for the suggested regime in Chapter 5, objectives, principles, procedures and other mechanisms are evaluated with reference to the key research questions and international best practice; evidence of practice to demonstrate effectiveness will be indicated wherever possible. In more detail, chapter summaries are as follows.

Chapter 2 concerns southwest Asia. It analyses the Arabian Gulf/Gulf of Oman Convention, and the Red Sea/Gulf of Aden Convention, together with the numerous detailed protocols that has been elaborated thereunder. The objective of both is the conservation of the Arabian Gulf and Gulf of Oman, and Red Sea and Gulf of Aden environments respectively, including the prevention, abatement and combating of marine pollution. Each contains general and specific obligations, including the prevention of pollution from ships, from dumping, and from land-based sources; from exploration and exploitation; and from other human activities. They furthermore contain obligations to conduct EIAs and for liability and compensation.

Chapter 3 examines central Asia. It first evaluates the Caspian Sea Convention. The objective of this is to protect the Caspian environment from all sources of pollution including the protection, preservation, restoration and sustainable and rational use of the biological resources. It 
contains guiding principles and obligations such as EIAs. It also evaluates the water resource arrangements for the Aral Sea: the Joint Management and Conservation of Interstate Water Resources Agreement, the International Fund for Saving the Aral Sea Agreement, and the Interstate Commission for Water Coordination Statute. In addition, Chapter 3 considers the Environmental Protection for Sustainable Development Convention. The purpose of this last treaty is to ensure the effective environmental protection and improvement of the environment, including the rational use of natural resources, and to reduce and prevent transboundary environmental damage through harmonization and coordination. Principles and provisions for specific environmental media are included, together with cooperation, access to information and public participation.

Chapter 4 is focused on southeast Asia. It explains and analyses the Mekong Agreement. This is focused on cooperation in relation to sustainable development, and the utilization, management and conservation of the water and related resources to optimize the multiple-use and mutual benefits of all riparians, and to minimize harmful effects. Obligations on the Mekong River Commission (MRC) include creating a Basin Plan, and on Parties to notify and consult in relation to development, principally dam-building. Chapter 4 will also explain and analyse the ASEAN Conservation Agreement and related Centre for Biodiversity Agreement. The first contains many broad environmental objectives and obligations, as well as specific provisions on conserving genetic diversity, endangered and endemic species, vegetation cover and forest resources, soil, water and air. EIAs, advance notification, and appropriate consultation should all be undertaken prior to any proposed utilization of the shared resources. Chapter 4 finally evaluates the Haze Pollution Agreement. This aims to prevent, monitor and mitigate negative transboundary effects arising from land and forest fires through national efforts and international cooperation. Measures to control the sources of fires; develop monitoring, assessment and early warning systems; exchange information and technology; and provide mutual assistance, are all included.

Chapter 5 looks to south and east Asia. It considers the environmental governance currently in place in south Asia, in particular as supported by SACEP and SAARC. The latter has produced three relevant agreements: the Environmental Cooperation Convention, the Rapid Response to Natural Disasters Agreement, and the Energy Cooperation (Electricity) Agreement. These are all considered along with the Indus Waters Treaty, climate change arrangements, the Malé Declaration on air pollution, and the Regional Seas Programme for the South Asian Seas. Significantly, as 
indicated, it also evaluates the SAARC and SACEP institutional arrangements that operate independently of the agreements promulgated, which may form the basis for any Third Pole regime. In east Asia, it furthermore analyses the Tumen Agreements. The aim of both is to attain environmentally sound and sustainable development of northeast Asia and the Tumen River Economic Development Area, with reference to international and domestic law and the requirements of MDBs/IFIs. Obligations are also present for EIA and environmental management plans. Chapter 5 also examines the informal arrangements for air pollution in northeast Asia, and the UNEP Regional Seas Programme for East Asia.

Significantly, Chapter 5 analyses the prospects for establishing an additional environmental regime for the Third Pole, and China's role in relation to this. This is based on the conclusions from each of the preceding chapters and in the context of the particular environmental issues and the geopolitics of this subregion. While most of the regimes in the subregions discussed in Chapters $2-5$ are based on formal agreements, and the majority have been adopted (and in many instances ratified and applied with some - albeit limited - success), the governance of the Third Pole is yet to be conceived, fully proposed and evaluated. Finally, Chapter 5 answers the remaining central research questions not answered in the previous chapters and summarizes findings. It also emphasizes the likely challenges. These include - despite the significance and necessity of engaging China (and other key states) in environmental regimes, and particularly in the Third Pole subregion - that a reluctance to cede national sovereignty to international law-making may impede progress. Nonetheless, other successful examples of Chinese involvement in the implementation of and compliance with international law (such as the World Heritage Convention), ${ }^{102}$ together with shared interests between China and other states in resolving the major environmental issues of the twenty-first century (climate change uppermost), are indications of promise for the future. Research directions going forward are elaborated at the end of Chapter 5.

102 Convention Concerning the Protection of the World Cultural and Natural Heritage (Paris, 16 November 1972) 1037 UNTS 151, in force 17 December 1975. 